\title{
A PROSPECTIVE TRIAL OF POSTOPERATIVE LODOXAMIDE (ALOMIDE) ON PTERYGIUM RECURRENCE
}

\author{
V.A. ESSUMAN ${ }^{1}$, C.T. NTIM-AMPONSAH ${ }^{1 A}$, G.K. VEMUGANTI ${ }^{2}$ and T.A. NDANU ${ }^{3}$ \\ ${ }^{1}$ Ophthalmology Unit, Department of Surgery, University of Ghana Medical School, Ghana, ${ }^{2}$ Ophthalmic \\ Pathology Service, LV Prasad Eye Institute, Hyderabad, India, ${ }^{3}$ University of Ghana Dental School, College \\ of Health Sciences, University of Ghana. $1^{A}$ Deceased in April 2012.
}

DOI: http://dx.doi.org/10.4314/gmj.v49i4.4 Corresponding Author: Dr. V.A. Essuman

Email:vadessuman@yahoo.com

Conflict of Interest: None declared

\section{SUMMARY}

Background: To compare pterygium recurrence after bare sclera excision with and without topical lodoxamide.

Design: Randomised double-blind study.

Methods: The study involved 61 patients with primary pterygia who had bare sclera excision after informed consent. They were post-operatively treated by either of 2 treatment groups for 4 weeks, with a 30-months follow-up: Controls/placebo $=$ Guttae prednisolone $1 \%$ with chloramphenicol $0.5 \%$ plus guttae distilled water. Test group $=$ Guttae prednisolone $1 \%$ with chloramphenicol $0.5 \%$ plus guttae lodoxamide $0.1 \%$.

Results: Sixty patients were analysed. Control Group had 20 females and 10 males, aged 28-69.5 years, mean 42.0( \pm 10.9$)$. Test Group had 15 males and 15 females, aged 17-75 years, mean $46.0( \pm 12.6)$. Recurrence for the Test Group was 11(37\%) within 30 months and 11(37\%) for the Control Group within 30 months $\quad(\mathrm{OR}=1.00, \quad \mathrm{CI}: \quad 0.35-2.858)$. Main complications encountered were granuloma: $7(11.7 \%)$ from the controls and 5(8.3\%) from the test group; restriction in the motility of medial rectus muscle: $1(1.7 \%)$ from each group; persistent vascularisation at site of excision: 1(1.7\%) from each group and adherence leukoma with uveitis $1(1.7 \%)$ from the control group, the latter also had persistent peripheral corneal epithelial defect later resulting in a dellen. No significant difference was found between the treatment groups with respect to recurrence, type and time of complications, orientation and morphology of pterygium, $\mathrm{P}>0.05$.

Conclusion: The recurrence of pterygium is high (about one third) with or without the use of adjuvant lodoxamide.

Keywords: Pterygium, epidemiology, bare sclera, Lodoxamide (Alomide), recurrence.

\section{INTRODUCTION}

Pterygium is a degenerative, benign, fibrovascular growth, which extends from the conjunctiva into the cornea. Treatment is surgical but high recurrences rates are primarily seen after bare sclera surgery, $24 \%$ to over $80 \%{ }^{1-4}$ The quest to reduce these unacceptable high rates of recurrence associated with bare sclera surgery have led to various adjuvants being used over the years. These include B-radiation with Strontium-90 given recurrence rates of $0.5-20 \%, 5,6$ chemotherapeutic agents such as mitomycin-C, 0 $38 \%{ }^{7-9}$ and conjunctival autograft, $2-39 \%$. ${ }^{1,2,9,10}$ Conjunctival autograft results in remarkably few complications but B-radiation and the chemotherapeutic agents such as mitomycin-C have potentially more serious complications such as cataract, aseptic necrosis of the sclera and cornea, with attendant perforation, severe intraocular inflammation and infection. ${ }^{711-13}$

Some studies, using histology and immunohistochemistry, have demonstrated the presence of mast cells and eosinophils in excised pterygia (both primary and recurrent types). These findings have suggested that an immunologic mechanism or allergy, possibly of Types 1,3 and 4 hypersensitivity, may contribute to the pathogenesis of pterygium. ${ }^{14-17}$ In addition, the type of mast cells found in both primary and recurrent pterygia have been found to be tryptase-positive, chymase- positive mast cells, a finding also seen in active vernal conjunctivitis and giant papillary conjunctivitis, both with immune based pathogenesis. ${ }^{17,18}$

These findings suggest that anti-allergic drugs such as Lodoxamide, which act as mast cells stabiliser inhibiting in vivo Type 1 immediate hypersensitivity reaction, ${ }^{19}$ and Olopatadine, a relatively selective H1receptor antagonist and inhibitor of histamine release from the mast cells, ${ }^{20}$ may help to reduce recurrence. 
Other factors implicated in the pathogenesis of pterygium include ultraviolet rays and dusty environment, $^{21}$ conditions which are prevalent in tropical countries like Ghana. Pterygium is very common in Ghana and the surgical procedure commonly performed is excision using bare sclera technique. Anecdotal observation has shown both successes and recurrences after long-term follow up in years. In recent years, the use of some of the adjuvants to bare sclera surgery, such as conjunctival autografts and antimetabolites, by some ophthalmologists in Ghana have been on the increase. There has not been any published data in the literature from Ghana on the recurrence rate of pterygium after bare sclera excision with adjuvant treatment. The study therefore aimed at comparing recurrence rate of bare sclera technique with and without post-operative adjuvant lodoxamide eye drops in Ghanaians.

\section{MATERIALS AND METHODS}

Patients undergoing surgical treatment for primary pterygium were assessed for eligibility into a prospective, randomised-double blind study. Sixty-one of these patients who satisfied the inclusion criteria were admitted into the study, after obtaining ethical clearance from the University of Ghana Medical School Ethics and Protocol Review Committee. The study was completed in the year 2004.

The sample size was calculated based on recurrence estimates for bare sclera technique of $30 \%$ which falls within those reported in the literature ranging from 24 $80 \%{ }^{3-6}$ at $95 \%$ confidence levels and $80 \%$ statistical power (1- $\beta)$. This gave us a sample estimate of 32 per group. Patients were eligible if they had a primary pterygium with neither external eye pathology nor previous eye surgery. Only those who gave consent were recruited. The history and examination of all the patients were obtained through a structured questionnaire. The history included; occupation (outdoor or indoor), use of spectacles, allergy or atopy, and any other ocular disease.

Complete ocular examination noted the gross features of the pterygia (fleshy (vascularised), intermediate, or atrophic) based on the translucency of the pterygium, presence or absence of calcification, its laterality (unilateral or bilateral), location (nasal, temporal or kissing), its extent into cornea and encroachment on the visual axis. The morphology of the pterygium was classified as:

T1 - transparent/ atrophic

$\mathrm{T} 2$ - intermediate

T3 - fleshy

\section{Excision of pterygium}

All the patients had retrobulbar anaesthesia with xylocaine/adrenaline $2 \%$, and measurement of the dimensions of the pterygia done intra-operatively using callipers and a $4 x$ Loop. Excision of the pterygium was by the bare sclera technique, in which the head of the pterygium was detached from the cornea by careful superficial keratectomy with number 15 scapel blade, and a triangular excision of the rest of the pterygium with overlying conjunctiva and underlying tenons, leaving a bare sclera of about $5 \mathrm{~mm}$ from the limbus.

Haemostasis was achieved, where necessary, by pressure padding. Chloramphenicol ointment and guttae homatropine $2 \%$ were instilled immediately and the eye padded overnight. Postoperatively, from day after surgery till four (4) weeks, patients were grouped and treated by either 1 or 2 treatment below in a random, double masked way: Group.1= Guttae prednisolone $1 \%$ with chloramphenicol $0.5 \%$ q.i.d. plus guttae distilled water (placebo) t.i.d. Group. $2=$ Guttae prednisolone $1 \%$ with chloramphenicol $0.5 \%$ q.i.d. plus guttae lodoxamide $0.1 \%$ three times daily.

All surgeries were performed by the same surgeon on outpatient basis. All excised tissues were sent for histopathological confirmation of pterygium. Recurrence was diagnosed when a fibrovascular growth occurred, in the position of the previously excised pterygium, crossing the limbus and extending onto the cornea for any distance. Postsurgical conjunctival granulomas were left untreated and all disappeared within one month.

\section{Treatment concealment}

The drugs, except the lodoxamide were produced and bottled by the Drug Manufacturing Unit of the hospital, which relabelled all 4 drugs according to the treatment groups above, concealing their names.

\section{Patients' allocation and randomization}

An independent person using systematic random sampling did the allocation of the patients. Group membership was determined by randomly selecting the first person's group by toss of a coin. The subsequent persons were alternately assigned their groups.

For those with bilateral pterygia, and also kissing pterygia, the eye or the orientation of the pterygium to be enrolled in the study was predetermined at the beginning of the study for all patients, by tossing a coin, resulting in all right eyes and in the case of kissing pterygia, nasal type being selected for 
inclusion. Patients were evaluated post-operatively on days 1 and 8 , then 1 month, 3, 6, 12, 18, 24 and 30 months thereafter. The group code was opened at the end of the 30 months.

\section{Statistical analysis}

Data was captured using Microsoft Office Excel and analysed using SPSS Version 16.0. Continuous numerical data was captured as Mean and Standard deviation (SD) and categorical data as percentages (\%). Chi-square test was used to compare proportions and student T-test used to compare means. Correlation analysis was used to establish linear associations for scale and ordinal variable while regression and logistic regression was employed to establish causal associations in the data. Odds ratio was used to estimate risk in the samples. Significance was set at $\alpha=0.05$.

\section{RESULTS}

\section{Demographics}

A total number of 61 patients were enrolled but data for 60 patients were analysed, 30 in each treatment group.

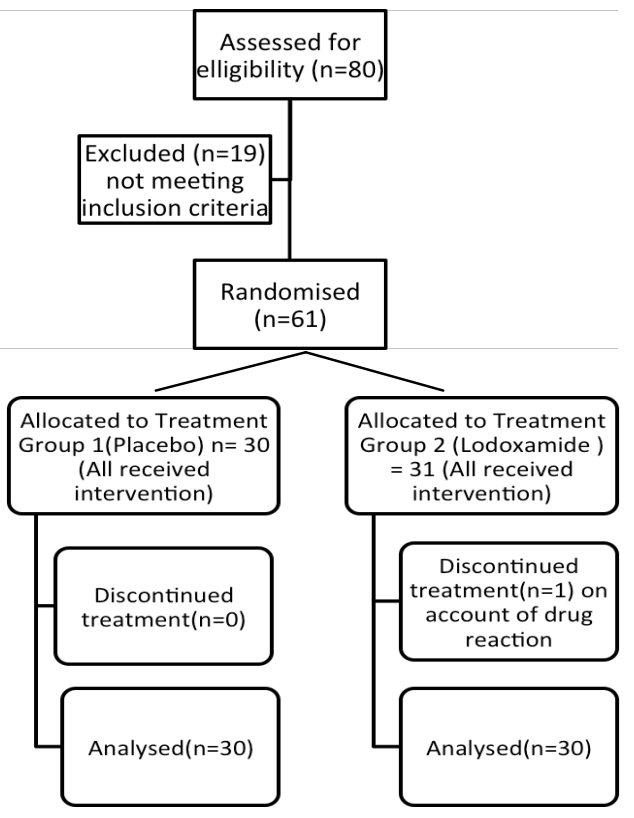

Figure 1 Diagram showing the flow of participants through each stage of study

Figure 1 shows the flow of patients through each stage of the study and Table 1 gives the clinical features of the 2 groups.
Treatment Group 1(Control/Placebo) had 20 females and 10 males, aged 28-69.5 years, Mean 42.0( \pm 10.9$)$. Treatment Group 2 had 15 males and 15 females, aged 17-75 years, Mean 46.0 $( \pm 12.6)$.

There was no statistical difference between the 2 treatment groups with respect to gender $(p=0.295)$ and age $\mathrm{p}>0.05$.

There was no statistical difference between the 2 treatment groups with respect to type and time of complications, recurrence (time and rate), laterality, orientation and morphology of pterygium, $\mathrm{P}>0.05$. Table 1, and Figures 2.

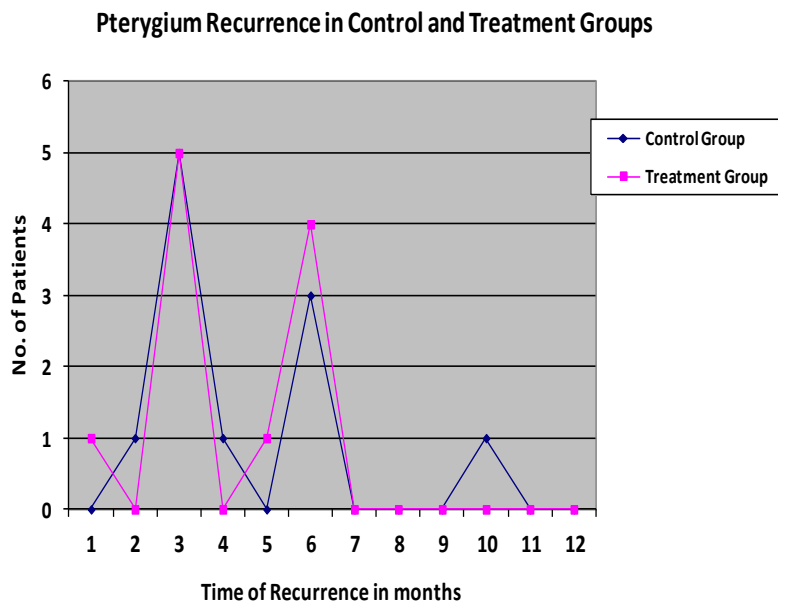

Figure 2 Pterygium Recurrences in Control and Treatment Groups

\section{Recurrence}

Out of 30 patients in each group, 11 (36.7\%) had recurrence respectively. The Odds ratio, OR, for the 2 groups $=1.00$ (CI: 0.35-2.858). The mean time of recurrence for the control group was $4.5( \pm 2.2)$ months, while that of the test group was $4.1( \pm 1.8)$ months, $p>0.05$. The overall recurrence time showed a bimodal pattern at 3months: $10(45.0 \%)$ and at 6 months: $7(31.8 \%)$ (Figure 2)

\section{Complications}

Main complications encountered were granuloma: $7(11.7 \%)$ from the controls and $5(8.3 \%)$ from the test group; restriction in the motility of medial rectus muscle: 1(1.7\%) from each group; persistent vascularisation at site of excision: $1(1.7 \%)$ from each group and adherence leukoma with uveitis $1(1.7 \%)$ from the control group, the latter also had persistent peripheral corneal epithelial defect for about 2 weeks post-operation, later resulting in a dellen. 
No significant difference was found between the two groups with regards to complications encountered, $\mathrm{p}=0.51$. Table 1

Table 1 Clinical features of patients with pterygia.

\begin{tabular}{|c|c|c|c|c|}
\hline \multicolumn{2}{|l|}{ Characteristics } & \multirow{2}{*}{$\begin{array}{l}\text { ControlGP } \\
(1), \mathbf{N}(\%) \\
20(66.7) \\
4(13.3) \\
6(20.0)\end{array}$} & \multirow{2}{*}{$\begin{array}{l}\text { Treatment } \\
\text { GP (2), } \\
\text { N (\%) } \\
17(63 \%) \\
9(14 \%) \\
4(22 \%)\end{array}$} & \multirow{2}{*}{$\begin{array}{l}\begin{array}{l}\text { P- } \\
\text { Value }\end{array} \\
0.277\end{array}$} \\
\hline Laterality & $\begin{array}{l}\text { Bilateral } \\
\text { Left } \\
\text { Right }\end{array}$ & & & \\
\hline Orientation & $\begin{array}{l}\text { Kissing } \\
\text { Nasal } \\
\text { Temporal }\end{array}$ & $\begin{array}{l}1(3.3) \\
29(96.7) \\
0\end{array}$ & $\begin{array}{l}1(3.3) \\
28(93.3) \\
1(3.3)\end{array}$ & 0.601 \\
\hline Morphology & $\begin{array}{l}\text { Calcification } \\
\text { No Calcification }\end{array}$ & $\begin{array}{l}10(16.7) \\
20(33.3)\end{array}$ & $\begin{array}{l}10(16.7) \\
20(33.3)\end{array}$ & 1.00 \\
\hline Vascularity & $\begin{array}{l}\mathrm{T} 1 \\
\mathrm{~T} 2 \\
\mathrm{~T} 3\end{array}$ & $\begin{array}{l}2(6.7) \\
21(70.0) \\
7(23.3)\end{array}$ & $\begin{array}{l}5(16.7) \\
20(66.7) \\
5(16.7)\end{array}$ & 0.635 \\
\hline Allergy to Dust & $\begin{array}{l}\text { No } \\
\text { Yes }\end{array}$ & $\begin{array}{l}22(73.3) \\
8(26.7)\end{array}$ & $\begin{array}{l}19(63.3) \\
11(36.7)\end{array}$ & 0.580 \\
\hline Asthma & $\begin{array}{l}\text { No } \\
\text { Yes }\end{array}$ & $\begin{array}{l}27(90.0) \\
3(10.0)\end{array}$ & $\begin{array}{l}22(73.3) \\
8(26.7)\end{array}$ & 0.191 \\
\hline $\begin{array}{ll}\text { Allergy } & \text { to } \\
\text { Perfume } & \end{array}$ & $\begin{array}{l}\text { No } \\
\text { Yes }\end{array}$ & $\begin{array}{l}22 \\
8\end{array}$ & $\begin{array}{l}21 \\
9\end{array}$ & 1.000 \\
\hline Complications & $\begin{array}{l}\text { No } \\
\text { Yes }\end{array}$ & $\begin{array}{l}19(63.3) \\
11(36.7)\end{array}$ & $\begin{array}{l}24(80.0) \\
6(20.0)\end{array}$ & 0.508 \\
\hline
\end{tabular}

T1 - transparent/ atrophic; T2 - moderately vascularised / fleshy; T3 - more vascularised / fleshy. GP - Group

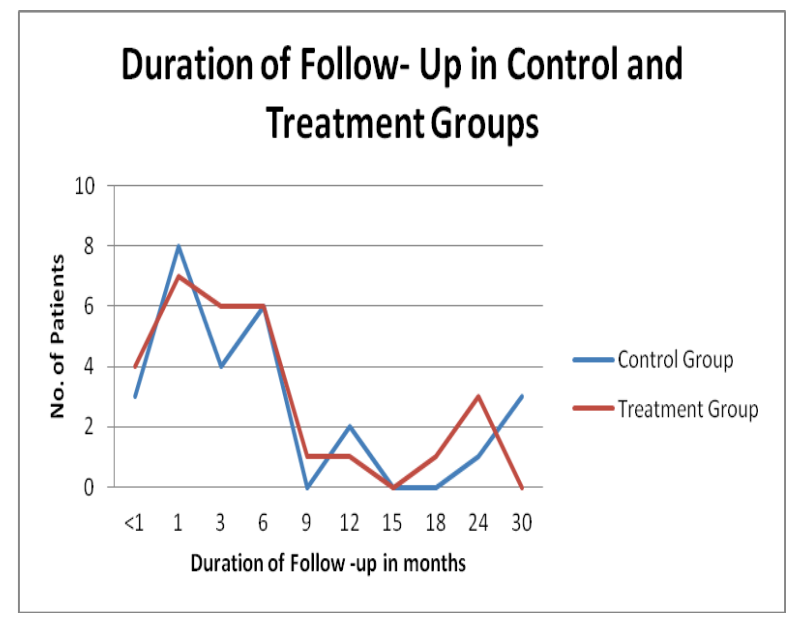

Figure 3 Duration of follow-up in Control and Treatment Groups

One patient who had persistent headaches, ocular irritation as well as redness with the use of one treatment was taken out of the study and referred to an ophthalmologist for treatment. His group code was the test treatment group (code broken at the end of the study).
Patients were followed up for up to 30 months (Group 1 for 1-30 and group 2 for 1-24 months), $p>0.05$, with progressively significant numbers being lost to follow up after 6 months (Figure 3).

\section{DISCUSSION}

This study showed no advantage of lodoxamide in preventing recurrence of pterygium. There was no statistically significant difference between the 2 treatment groups with respect to recurrence, type and time of complications, gender, age, laterality, orientation and morphology of pterygium. The overall recurrence $(37 \%)$ and intra-group recurrences $(37 \%)$ were high..

The bare-sclera technique, used alone as a method of treatment for pterygium, is associated with high recurrence rates. This is as compared to other forms of surgical treatment (such as conjunctival autograft, amniotic membrane graft and lamellar corneal transplants) or adjuvant treatments (such as beta irradiation, thiotepa and intra- and post-operative mytomycin-C). $3,7,11-13,22-24$

Although bare sclera excision is a commonly performed surgical procedure by ophthalmologists in Ghana, there is no published data from the country which has looked at the recurrence rate of bare sclera pterygium excision with adjuvant treatment. Hence, no comparison could be made with this study.

The high recurrence rates in this study (37\%) could be partly explained by the fact that the patients involved in this study continued to be exposed to abundant ultraviolet rays and dust for most times of the year. This is because although majority had indoor occupations, they continued to live in Ghana. Majority of the recurrences occurred within 6 months post-operative. This early recurrence in the first year post surgery supports other published data. ${ }^{25}$ The number of recurrences reduced thereafter.which could be due to the progressively high number lost to follow up after 6 months [Figure 3].

Ibechukwu in Jos, Nigeria had prospectively compared the effect of post-operative use of antibiotics, steroids and sodium cromoglycate (another mast cell stabiliser), after pterygium excision. He found sodium cromoglycate to be most effective in controlling pterygium recurrence, reducing it to $20 \%$ relative to $53.1 \%$ and $35.1 \%$ for the antibiotic and steroid groups respectively. ${ }^{13}$ This study, however, did not find any difference in recurrence between the lodoxamide and the control groups. 
This finding may corroborate findings from other studies, which have suggested that the type and increase in mast cells found in primary and recurrent pterygia were tryptase-positive, chymase- positive mast cells. The contribution of this type of mast cells to the pathogenesis of pterygium may not be immune system-related but may rather function through angiogenesis and tissue remodelling mechanism. ${ }^{15,26}$ This calls for further studies.

Additional data on quantification of mast cells with histochemistry or immunohistochemistry in both groups would have added value to the study. The strength of this study, however, is that it is the first randomised, double-masked study to determine the recurrence rate of pterygium excision with bare sclera technique with or without an adjuvant treatment in Ghanaians. This information, hopefully, would form a baseline for comparison with future studies within the same population. Such future studies may explore other effective, evidence-based forms of treatment (surgery with adjuvant treatments) for reducing the high recurrence rate associated with excision of pterygium. This is necessary since pterygium is a disease which is very common and is an important cause of ocular irritation and cosmetic disfigurement in the Ghanaian population. Finally, the finding should reinforce the need to completely abandon bare sclera technique alone as a surgical procedure for pterygium in Ghana.

\section{CONCLUSION}

In conclusion, the post-excision recurrence of pterygium is high (about one third) with or without the use of adjuvant lodoxamide.

\section{ACKNOWLEDGEMENT}

We are grateful to Paracelsus Pharmacy Ltd., the local representative of ALCON ltd, who donated the lodoxamide(Alomide) for the study; Miss Sussie Ashun who helped with the patient allocation and also with the distribution of the drugs; staff of the Pathology Department of Korle-Bu Teaching Hospital and the Ophthalmic Pathology Service, LV Prasad Eye Institute, Hyderabad, India who helped with the preparation of the pterygia specimens for histological analysis; and finally Mr Ankrah and staff of the Drug Manufacturing Unit of the Korle-Bu Teaching Hospital, Accra, Ghana, who helped with the drugs' preparation and labeling.

\section{REFERENCES}

1. Sebban A, Hirst LW. Treatment of pterygia in Queensland. Aust NZ J Ophthalmol 1991; 19: 1237.

2. Jaros PA, DeLuise VP. Pingueculae and pterygia. Surv Ophthalmol 1988; 33: 41-9.

3. Ashaye A.O. Pterygium in Ibadan. West African Journal of Medicine 1991;10: 232-243.

4. Retty I., Fregene A.O, Salomon K. Post-operative Beta irradiation of pterygium. Nig. Med. J 1973;3: 196-197.

5. Walter WL: Another look at pterygium surgery with postoperative beta radiation. Ophthal Plast Reconstr Surg 10:247-52, 1994.

6. Wilder RB, Buatti JM, Kittelson JM, et al: Pterygium treated with excision and postoperative beta irradiation. Int J Radiat Oncol Biol Phys 23:533-7, 1992.

7. MacKenzie FD, Hirst LW, Kynaston B, et al: Recurrence rate and complications after beta irradiation for pterygia. Ophthalmology 1991; 98:1776-80.

8. Mahar PS,Nwokora GE. Role of mitomycin C in pterygium surgery. Br J Ophthalmol 1993;77:4335.

9. Chen PP, Ariyasu RG, Kaza MD, et al. A randomized trial comparing mitomycin $\mathrm{C}$ and conjunctival autograft after excision of primary pterygium. Am J Ophthalmol 1995;120:151-60.

10. Lewallen S. A randomized trial of conjunctival autografting for pterygium in the tropics. Ophthalmology 1989;96:1612-4.

11. Gris O, Guell JL, del Campo Z: Limbalconjunctival autograft transplantation for the treatment of recurrent pterygium. Ophthalmology. 2000 107:270-3

12. Hsiao $\mathrm{CH}$, Chen JJ, Huang SC, et al: Intrascleral dissemination of infectious scleritis following pterygium excision. $\mathrm{Br} J$ Ophthalmol. 82:29-34, 1998.

13. Ibechukwu B.I. Post-operative Management of Pterygium in Jos, Nigeria- comparison of antibiotics, steroids and opticrom. East African Med J. 1992: 69; 490- 493.

14. Butrus S I, Ashraf M.F, Laby DM, et al. Increased numbers of mast cells in pterygia. $A m J$ Ophthalmol. 1995; 119:236-7.

15. Nakagami T, Murakami A, Okisaka S, et al. Mast cells in pterygium: number and phenotype. Jpn $J$ Ophthalmol. 1999;43:75-9.

16. Pinkerton O. D, Hokama Y, Shigemura L.A. Immunologic basis for the pathogenesis of pterygium. Am J Ophthalmol. 1984; 98:225-8. 
17. Liu L, Yang D. Immunological studies on the pathogenesis of pterygium. Chin Med Sci J. 1993; 8:84-8.

18. Irani AM, Butrus SI, Tabbara KF, Schwartz LB. Human conjunctival mast cells: distribution of MCT and MCTC in vernal conjunctivitis and giant papillary conjunctivitis. J Allergy Clin Immunol. $1990 \mathrm{Jul} ; 86(1): 34-40$.

19. FDA approved Alomide information for healthcare professionals. www.drugs.com/pro/alomide.

20. Patanol (Olopatadine Hydrochloride) - Summary. www.druglib.com/druginfo/patanol.

21. Sekelj S, Dekaris I, Kondza-Krstonijević E, et.al. Ultraviolet light and pterygium. Coll Antropol. 2007; 31 Suppl 1:45-7.

22. Fernandes M, Sangwan VS, Bansal AK, et al. Outcome of pterygium surgery: analysis over 14 years. Eye 2005; 19, 1182-1190.
23. Tan DTH, Chee SP, Dear KBG, et al. Effect of pterygium morphology on pterygium recurrence in a controlled trial comparing conjunctival autografting with bare sclera. Arch 1997; 115: 1235-1240.

24. Hirst LW. The treatment of pterygium. Surv Ophthalmol. 2003; 45: 145-180.

25. Hirst L. W, Sebban A, Chant D. Pterygium Recurrence Time. Ophthalmology. 1994; 101: 755-758.

26. Fatma Hüsniye $\mathrm{D} \prec$ LEK, Faruk ÖZTÜRK, Fatma AKTEPE1, Samet ERM $<f$, Fatih Mehmet MUTLU. Mast cells and angiogenesis in primary and recurrent pterygia. Turkish Journal of Pathology 2007;23(3):132-136. 